\title{
Genesis of Prolactinomas: Studies Using Estrogen-Treated Animals
}

\author{
Dipak K. Sarkar \\ Endocrine Program, Biomedical Division of the Center of Alcohol Studies and \\ Department of Animal Sciences, Rutgers, State University of New Jersey, \\ New Brunswick, N.J., USA
}

\begin{abstract}
Prolactin-secreting adenomas (prolactinomas) are the most prevalent form of pituitary tumors in humans. Our knowledge of the formation of these tumors is limited. Experimental work in animal has uncovered that estradiol exposure leads to prolactinoma formation via orchestrated events involving dopamine D2 receptors, transforming growth factor- $\beta$ (TGF- $\beta$ ) isoforms and their receptors, as well as factors secondary to TGF- $\beta$ action. Additionally, these studies determined that TGF- $\beta$ and b-FGF interact to facilitate the communication between lactotropes and folliculo-stellate cells that is necessary for the mitogenic action of estradiol. The downstream signaling that governs lactotropic cell proliferation involves activation of the MAP kinase p44/42-dependent pathway.
\end{abstract}

Copyright (C) 2006 S. Karger AG, Basel

Pituitary tumors are primarily adenomas; they account for approximately $10-15 \%$ of intracranial tumors. They cause significant morbidity due to local invasion, hypopituitarism or hormone hypersecretion $[1,2]$. Pituitary tumors are classified as either functioning and secreting excessive amounts of active hormones, or as endocrinologically inactive and secreting no hormones or inactive hormones. Pituitary tumors are also classified by virtue of their size into the arbitrary division of those less than $1 \mathrm{~cm}$ as microadenomas and those more than $1 \mathrm{~cm}$ as macroadenomas. Pituitary tumors secreting excess prolactin are characterized as prolactinomas. Prolactinomas are the most frequently occurring neoplasm in the human pituitary [3, 4]. In the general population, 1:2,800 men and 1:1,050 women are considered to have prolactinomas [5]. In human subjects, prolactinomas occur as both macroadenomas and microadenomas. In addition, mixed growth hormone and prolactin-secreting adenomas are documented to exist in a substantial number of acromegaly patients. 
Hyperprolactinoma is a condition in which plasma prolactin (PRL) levels are elevated above normal levels. Hyperprolactinemia, with elevation of serum prolactin of more than $200 \mathrm{ng} / \mathrm{ml}$, is characteristically associated with prolactinomas [6]. Hyperprolactinemia causes reproductive dysfunction such as amenorrhea, galactorrhea, and infertility in women [7]. Amenorrhea and galactorrhea may occur alone or together [8]. Up to $25 \%$ of patients with secondary amenorrhea have been diagnosed with hyperprolactinemia. Many of these patients showed micro-prolactin adenomas or macro-prolactin adenomas in the pituitary. Although treatments that alter central dopaminergic neuronal functions cause an elevated serum PRL level, in most cases hyperprolactinemia is due to a pituitary tumor. In women, prolactinomas are mainly microadenomas. These microadenomas are rarely associated with hypopituitarism or central nervous system dysfunction. Idiopathic hyperprolactinemia, without demonstrable pituitary or hypothalamic disease, has also been identified. In men, prolactinomas are mainly macroadenomas [9]. These patients often exhibit gynecomastia, impotence, decreased libido, and reduced reproductive hormone levels [10].

The genesis of prolactinoma in lactotropes of the pituitary gland or other pituitary tumors remains for the most part a subject of speculation and debate because cells involved in the formation of adenoma may be derived from monoclonal or polyclonal expansion and may have phenotypes that change during tumor development and therefore are very hard to discern. However, information of genetic modifications that increase the risk factors for lactotropic tumors has begun to decipher from animal studies in which prolactinoma is induced by estrogen.

\section{Animal Model for Studying the Genesis of Prolactinomas}

\section{Aging Rats and Mice}

Prolactinomas are not only the most frequently occurring neoplasm in the human pituitary, but these tumors also commonly occur in laboratory animals. A $10-86 \%$ incidence of spontaneous pituitary adenomas was reported in male and old female rats of different strains, especially during aging [reviewed in 11]. The incidences of pituitary adenomas in aging Wistar male and female rats, Charles River COBS male rats, and Long-Evans female rats are 56\%, $10-51 \%$ and $56 \%$, respectively. Most of these adenomas in laboratory rats are prolactinomas. Evidence for aging-induced prolactinomas in humans is currently lacking.

\section{Estrogen-Treated Rats}

Pituitary tumors in experimental animals can be induced by estrogen. Most of these estrogen-induced pituitary tumors are PRL- or GH-secreting tumors [12]. In both sexes of rats, long-term elevation of serum estrogen causes hyperplasia 
and/or adenomas $[13,14]$. In Fischer-344 female rats, maintenance of constant elevated systemic estradiol level within the range of $100-300 \mathrm{pg} / \mathrm{ml}$ by subcutaneously implanting a $17 \beta$-estradiol-containing capsule induces prolactinomas very rapidly; within 2 weeks of estrogen implantation, significant hyperplasic response of lactotropes is evident $[11,13,15,17]$. Estradiol administration also induces prolactinomas both in ovary intact or ovariectomized ACI rats [16]. Synthetic estrogen diethylstilbestrol also causes pituitary hyperplasia and neoplasm in Fischer 344 rats [17].

Estrogen also appears to increase the risk factors for prolactinomas in humans. There are reports of the development of prolactinemia in a male to female transsexual receiving massive doses of estrogen [19]. There is evidence of growth of microprolactinoma to a macroprolactinoma during estrogen therapy [20]. Women taking oral estrogen contraceptive showed higher PRL levels [21]. Women using oral contraceptive due to menstrual irregularities showed a 7- to 8-fold higher incidence of prolactinomas [22]. Data suggest that some women are more sensitive to the lactogenic effects of exogenous estrogen and, therefore, may be at greater risk for developing prolactinomas [23]. During pregnancy, estrogen levels elevate and the number of prolactin-secreting cells and serum PRL content increases. These elevated levels of estrogen are associated with symptomatic pituitary tumor enlargement in up to $30 \%$ of women with macroadenomas and may result in persistent hyperprolactinemia and postpartum amenorrhea or galactorrhea [24]. However, the risk for development of significant clinical symptoms related to tumor expansion is less than $2 \%$ in pregnant women with microadenomas [9]. There appears to be a close association between the use of oral estrogenic contraceptives and the onset of amenorrhea, often accompanied by galactorrhea [25-27]. Certain subsets of humans and animals are more sensitive to estrogen's mitogenic properties than the general population $[28,29]$. Hence, estrogen can be considered a risk factor for the development of prolactinomas in some laboratory animals and in a certain population of humans. At present, there is no answer as to why some humans and animals are more responsive to estrogen's actions. However, it is interesting to note that there are slight structural differences in the pituitaries of estrogensensitive Fischer-344 and estrogen-insensitive Sprague-Dawley rats, including a difference in the number of supporting folliculo-stellate cells [30]. The differences in folliculo-stellate cell numbers between these two strains could be significant in tumorigenesis because these cells are a major source of bFGF, which regulates lactotropic cell proliferation [31].

\section{Alcohol-Treated Rats}

Several reports show evidence for the existence of high levels of PRL in chronic alcoholic men and women. In a study conducted by European scientists, 
include organochlorine pollutants such as PCBs and DDT, which are known to persist in the environment. Experimental studies have confirmed that DDT mimics estrogen in MCF-7 cells [45]. Bisphenol A (BPA) is the monomeric component of polycarbonate plastics used in many consumer products and has estrogenic activity in MCF-7 cells in vitro [46]. BPA has been shown to induce hyperprolactinemia in estrogen-sensitive Fisher 344 rats by increasing PRL gene expression in the pituitary gland. Furthermore, BPA exerts its influence at the PRL gene transcription level by activating the estrogen response element (ERE) in pituitary cells [47]. Although there is a body of evidence to support xenoestrogens as a possible public health hazard, the carcinogenic potency of these compounds is much lower than that of estradiol [48].

\section{Cell Cycle, Genomic Instability, and Tumorigenesis in Lactotropes in Estrogen-Treated Rats}

\section{Factors Regulating Estrogen Mitogenic Action}

A number of factors are both estrogen-dependent and affect lactotropic proliferation, differentiation, and/or transformation. However, the relatedness of these factors in the mediation of estrogen action on cell functions is not well understood. Some such estrogen-regulated factors include epidermal growth factor (EGF), platelet-derived growth factor (PDGF), insulin-like growth factor (IGF)-1, transforming growth factor- $\alpha$ (TGF- $\alpha$ ), basic fibroblast growth factor (bFGF), fibroblast growth factor-4 (FGF-4), interleukin-2 (IL-2) and IL-6, nerve growth factor (NGF), and transforming growth factor- $\beta$ (TGF- $\beta$ ). A stimulatory action for EGF, TGF- $\alpha$, PDGF, IGF-1, and IGF-2 is shown on mesenchymal cell growth. EGF, TGF- $\alpha$, IGF-1 and IGF-2 also stimulate epithelial cell growth [49]. During the developmental period, estrogen can stimulate the growth of all cell types; however, in the adult, estrogen action is restricted primarily to epithelial cells [50]. It is not known why such a dichotomy exists in the adult. It could be due to expression or lack of expression of inhibitory or stimulatory factors that interact with estrogen. Estrogen's action on epithelial cells often depends on the presence of mesenchymal cells [51]. This is yet another way in which estrogen-varied actions could occur through common receptors. The response to estrogen would depend not only on the cell that displays proliferation or differentiation but also on neighboring cells. This is supported by the fact that estrogen actions in some cases can be displayed only in vivo or in specific culture conditions. Although the actions of many of these estrogen-responsive growth regulatory factors have been tested in tumor lactotropes (e.g. GH3 cells) or in mixed pituitary cell populations [52-58], the actions of most of these factors in primary lactotropes have not been tested or 
persistent hyperprolactinemia was observed in 16 alcoholic women during a 6-week treatment trial [32]. These patients reported daily alcohol intake of $170 \mathrm{~g}$ for a period between 2 and 16 years period but had no clinical evidence of alcoholic liver cirrhosis. In a study reported by Japanese scientists, 22 of 23 women admitted for alcoholism treatment had PRL levels above normal that ranged between 27 and $184 \mathrm{ng} / \mathrm{ml}$. These women reported drinking an average of $84.1 \mathrm{~g}$ of alcohol each day for at least 7 years. None of these patients showed liver cirrhosis, but 10 had hepatitis and the rest had fatty liver [33]. Studies conducted in a Massachusetts general hospital in the US reported hyperprolactinemia $(22-87 \mathrm{ng} / \mathrm{ml})$ in 6 of 12 alcohol-dependent women who had a history of drinking 75-247g of alcohol per day for a minimum period of 7 years [34]. Alcoholinduced hyperprolactinemia is also reported in healthy, well-nourished women during residence on a clinical research ward for 35 days [35]. Sixty percent of women in the heavy drinker category (blood alcohol level 109-199 mg/dl) and $50 \%$ of moderate drinkers (blood alcohol levels $48-87 \mathrm{mg} / \mathrm{dl}$ ) showed elevated PRL levels, and many of these drinkers had elevated PRL several days after cessation of drinking. Alcohol-induced hyperprolactinemia was also evident in 66 postmenopausal women [36]. The increase in PRL in these patients, however, was associated with increased androgen conversion to estradiol, possibly due to liver cirrhosis. Alcoholic men also showed elevated plasma levels of PRL [37-39]. Male alcoholic patients frequently show evidence of feminization that is manifested by gynecomastia, spider angiomata, palmar erythema and changes in body hair patterns [10]: a potential role for PRL and estradiol in the pathogenesis for the observed feminization. Thus, it appears that chronic alcohol administration in humans causes increased estrogen production and PRL elevation.

Alcohol-induced hyperprolactinemia has also been demonstrated in nonhuman primates [40]. Studies conducted in macaque female monkeys showed that in some, but not all, of the monkeys, the PRL levels were elevated after chronic self-administration of high doses of alcohol $(3.4 \mathrm{~g} / \mathrm{kg} /$ day). Interestingly, in one of these monkeys, immunocytochemical examination of the pituitary gland showed apparent pituitary hyperplasia. In laboratory rats, chronic ethanol administration increases plasma PRL levels and pituitary weight in cyclic female rats and ovariectomized rats as well as potentiating estrogen mitogenic effects in ovariectomized female rats $[42,43]$. Therefore, clinical as well as animal data suggest that ethanol consumption is a positive risk factor for prolactinomas and hyperprolactinemia, possibly due to ethanol's ability to increase endogenous estrogenic activity.

Xenoestrogen-Treated Rats

Xenoestrogens are environmentally occurring chemicals that mimic the action of estrogen by binding to estrogen receptors [44]. Examples of xenoestrogens 
confirmed. Also, their actions on the lactotropes in the presence of pituitary mesenchymal variant folliculo-stellate cells have not been tested. Additionally, overexpression of many of these factors using a transgenic approach have resulted only in hyperplasia, and they resulted in adenoma formation only in old age and/or only in females, suggesting that endogenous estrogens are a requirement [59-61]. Therefore, the role of these growth factors in the mechanisms leading to tumorigenesis could not be critically evaluated. However, substantial evidence is now available to show that a disruption of the TGF- $\beta$-regulated cell growth balance is critical in the development of prolactinoma in the pituitary.

\section{Cell Growth Balance by TGF- $\beta$ Isoforms}

The TGF- $\beta$ family of peptides includes many related factors that exert numerous actions. In mammals, TGF- $\beta$ is found in three highly homologous isoforms that exert their actions via heteromeric complexes of type I and type II receptors. TGF- $\beta 1$ is the most well characterized of the three TGF- $\beta$ s (TGF- $\beta 1$, TGF- $\beta 2$ and TGF- $\beta 3$ ) [62]. These peptide growth factors function in cell proliferation, differentiation, embryogenesis, tissue repair, and cell adhesion. In most epithelial cell types, TGF- $\beta 1$ acts as a negative growth regulator [63]. In mesenchymal cells, TGF- $\beta 1$ has been shown to either increase or decrease cell proliferation. TGF- $\beta 1$ can block the mitogenic actions of PDGF, FGF and EGF in certain cell types $[63,64]$. Given the important regulatory role of TGF- $\beta 1$ in controlling cell proliferation, it follows that a reduction in TGF- $\beta 1$ could have implications on cell transformation.

TGF- $\beta 1$ is produced in and secreted by pituitary lactotropes [65]. TGF- $\beta 1$ is a potent inhibitor of estrogen-induced lactotropic proliferation and PRL secretion $[65,66]$. Intrapituitary administration of TGF- $\beta 1$ resulted in inhibited PRL release, decreased pituitary weight, and reduced DNA synthesis in estrogentreated Fischer 344 rats. The inhibitory response to TGF- $\beta 1$ is reduced in anterior pituitary cell lines, including the prolactin-secreting PR1 cell line and the $\mathrm{GH}$ and prolactin-secreting GH3 cell line. Both of these cell lines show low levels of TGF- $\beta 1$ and its type II receptor (T $\beta R-I I)$ mRNA [67]. Lactotropes exposed to estrogen express reduced levels of T $\beta$ R-II and TGF- $\beta 1[68,69]$. TGF- $\beta 1$ has been shown to interfere with the mitogenic actions of several growth-promoting agents including FGF, EGF and IL-1 [64]. This leads to the possibility that the mitogenic action of estrogen could involve its ability to decrease TGF- $\beta 1$ levels, thereby allowing an increase in the levels of positive growth regulators.

\section{Differential Expression of TGF- $\beta$ Isoforms}

In addition to TGF- $\beta 1$, lactotropes also produce and secrete TGF- $\beta 3$ [70]. Interestingly, however, TGF- $\beta 1$ expression is reduced in lactotropes after estradiol 
exposure, while TGF- $\beta 3$ expression is increased after the steroid treatment. Though the finding that a stimulus causes differential expression of two TGF- $\beta$ isoforms in a single cell type is extremely novel, it is not unexplainable. Each of the TGF- $\beta$ isoforms is the product of a separate gene, each with distinct regulatory regions. Furthermore, it has been shown that the TGF- $\beta 1$ promoter has no TATAA box and is regulated principally by AP- 1 sites, whereas both the TGF- $\beta 2$ and TGF- $\beta 3$ promoters have TATAA boxes as well as AP- 2 sites and cAMPresponsive elements [71]. The AP-1 sites were previously thought to be specific for fos/jun transcription factors; however, it is now known that AP-1 sites can serve as nonclassical estrogen responsive elements [72]. Recently, Yang et al. [74] have demonstrated that estradiol selectively stimulates transcription of TGF- $\beta 3$ in bone cells. This effect of estradiol does not occur via a classical estrogen-responsive element (ERE), but rather via an alternative estrogensensitive sequence. This raises the possibility that the pituitary may be a site where this alternative response element on the TGF- $\beta 3$ gene is activated.

\section{Opposing Actions of Two TGF- $\beta$ Isoforms}

In the lactotropes, the production of TGF- $\beta 1$ and TGF- $\beta 3$ not only differ under estrogenic condition, but these two peptides also act differently in the presence of estrogen. Unlike TGF- $\beta 1$, TGF- $\beta 3$ stimulates lactotropic cell proliferation in the presence of estrogen. In the absence of estrogen, TGF- $\beta 3$ has a minimal effect on lactotropic cell proliferation [31]. Another interesting observation is that while TGF- $\beta 1$ neutralizing antibody failed to prevent estradiol's mitogenic action, it potentiated the cell-proliferating action of TGF- $\beta 3$ [70]. On the other hand, TGF- $\beta 3$-neutralizing antibody inhibited lactotropic cell proliferation by estradiol. These data indicated that, unlike many other tissues, TGF- $\beta 1$ and TGF- $\beta 3$ have opposite actions on lactotropic cell proliferation. Furthermore, simultaneous suppression of the growth inhibitory TGF- $\beta 1$ and activation of the growth stimulatory TGF- $\beta 3$ may be a mechanism that estradiol uses to induce lactotropic cell proliferation.

\section{Role of TGF- $\beta$ Receptors in Mediation of TGF- $\beta$ Isoform Actions}

The literature suggests that the different isoforms of TGF- $\beta$ act using similar receptor complexes (TGF- $\beta$ type I and TGF- $\beta$ type II receptors) to control growth response $[62,74]$. However, the affinity for each ligand may vary [75]. The opposing actions of TGF- $\beta 1$ and TGF- $\beta 3$ on estrogen-induced lactotropic proliferation raise the questions of how the two isoforms could act differentially at the same receptor site, and of why the TGF- $\beta 3$ that lactotropes produce would not be self-inhibitory. One explanation for TGF- $\beta 3$ 's inability to be selfinhibitory is that the TGF- $\beta$ receptors on lactotropes have a low affinity for TGF- $\beta 3$ [76]. Another possibility is that estrogen suppresses TGF- $\beta$ type II 
receptor that prevents the effect of TGF- $\beta$ on lactotropes [67]. It has been shown that TGF- $\beta 1$ inhibits lactotropic cell proliferation and that this response is mediated largely via the TGF- $\beta$ type II receptors [67]. The TGF- $\beta$ type I receptor in the pituitary has been implicated to be more involved in transcription responses evoked by TGF- $\beta$ [76]. Recently, it has been demonstrated that TGF- $\beta$ type II heterozygous 'knock-out' mice rapidly develop prolactinomas in response to estradiol exposure, unlike control mice [77]. A rat pituitary derived PR1 cell line, which has reduced levels of type II receptors [68, 76], displays very little or no growth-inhibitory response to TGF- $\beta 1$ [67]. However, in the presence of TGF- $\beta$ type I receptors and very low expression of TGF- $\beta$ type II receptors, TGF- $\beta 1$ inhibits PRL secretion in PR1 cells [76]. A similar scenario may exist in the case of FS cells, where the action of TGF- $\beta 3$ on gene transcription (production of b-FGF) predominates because of the normal expression of the type I receptor even though there is a low expression of the TGF- $\beta$ type II receptor under estrogenic conditions.

\section{Communication between Folliculo-Stellate Cells and Lactotropes}

In several tissues, it appears that the growth of cells depends not only on the mitogenic stimulus but also on cell-to-cell communication. For example, in uterine, ovarian, and mammary tissues, communication with mesenchymal cells facilitates the growth of epithelial cells [56]. Recently, it has been shown that FS cells regulate estradiol's cell-proliferating action on lactotropes [70]. FS cells are characterized by their stellate shape and long cytoplasmic processes, and they are largely devoid of secretory granules. S-100 immunoreactivity has proven to be a reliable marker of FS cells [78]. It has been suggested that FS cells perform several supportive functions, including regulation of phagocytosis [79], secretion of angiogenic factors [80], growth factors [31] and cytokines [81], as well as tropic and stem cell functions [82]. FS cells seem to be targeted by estrogen because they rapidly increase c-fos expression [83] in response to estrogen.

FS cells have been shown to participate in estrogen's mitogenic action on lactotropes [31]. Estradiol induces TGF- $\beta 3$ release from lactotropes. TGF- $\beta 3$ then acts on FS cells to release bFGF, which acts on lactotropes to increase cell proliferation. Thus, FS cells mediate estradiol's mitogenic action on lactotropes by releasing bFGF. FS cells also appear to determine the susceptibility of lactotropes to estradiol [84]. When co-transplanted with Fischer-344 pituitaries under the kidney capsule or co-cultured with Fischer-344-derived lactotropes in vitro, FS cells derived from Fischer-344 rats increased estradiol's mitogenic action. They also increased estradiol's growth-promoting action on Sprague-Dawley-derived lactotropes (which are normally minimally responsive 
to estrogen) in primary cultures. However, Sprague-Dawley-derived FS cells failed to increase estrogen's action on Fischer-344- or on Sprague Dawleyderived lactotropes. The levels of bFGF production and secretion by TGF- $\beta 3$ and estradiol were much higher in Fischer-344-derived FS cells than in Sprague-Dawley-derived FS cells. However, the growth response of lactotropes to bFGF was similar in both strains. These data suggest that cell-cell interaction between FS cells and lactotropes is important in the regulation of estradiol's mitogenic action on lactotropes and on the lactotropes' susceptibility to the steroid.

\section{Gap-Junctional Communication}

In the rat pituitary, formation of gap junctions between FS cells has been demonstrated using electron microscopic methods $[85,86]$. It has also been shown that FS cells communicate with other FS cells and with endocrine cells, including prolactin-secreting lactotropes [87]. The gap-junctional number in the anterior pituitary varied during the estrous cycle; it was highest in proestrous and in estrous and increased during middle to late pregnancy in rats [85]. This suggests that gonadal factors such as estradiol may regulate the rate of occurrence of gap junction in the anterior pituitary gland. Gap junctions connect the cytoplasmic domains of contacting cells to allow metabolic and ionic exchange between them [87]. Gap junctions consist of channel proteins called connexins, a family of proteins which, upon phosphorylation, increase permeabilization of the cells to molecules that are permeable through gap junctions [87]. Among the various types of connexins, connexin $43(\mathrm{Cx} 43)$ is known to express in astrocytes and the pituitary [88]. It has recently been shown that there were no changes in dye transfer or Cx43 in the FS cells following estradiol [89], indicating that the steroid had no direct effect on the molecular transfer across gap junctions in the FS cells. Since FS cells were shown to be activated by the TGF- $\beta 3$ secreted by the lactotropes [31], increased gap-junctional communication after TGF- $\beta 3$ may also underlie the modulatory role of FS cells in pituitary function and pathology. For instance, increased gap-junctional communication could lead to more FS cells being activated by lactotropes that could then lead to more bFGF release by the FS cells that, in turn, could further increase lactotropic cell growth.

\section{Mitogen-Activated Protein Kinase Signaling}

The MAP kinase $\mathrm{p} 44 / 42$ has also been shown to be regulated by estrogen [90]. The genomic effects of estrogen occur primarily through interaction with estrogen receptors [91]. The nongenomic actions of estrogen include activation of Ras [92], which in turn activates MAP kinase p44/42, Raf-1 [93], protein 
kinase C [94], protein kinase A [95], and Maxi-K channels [96]. These actions of estrogen may be mediated by a plasma membrane-associated estrogen receptor or by nonclassical estrogen receptors [97]. Studies of GH3 cells revealed that anti-estrogen receptor antibodies, directed against the hinge region of the estrogen receptor, blocked rapid activation of MAP kinase p44/42 and estradiol-induced PRL secretion [98]. In some cell systems, estradiol has been shown to activate a rapid MAP kinase p44/42 response within 3-5 min of treatment, as well as a delayed sustained response [91]. For rapid effects of estrogen, the receptors must be located in the plasma membrane. Delayed effects could be attributed to classical nuclear receptor and genomic action, as well to the paracrine action of estradiol through the secretion of growth factors [90]. Increasing evidence in recent years supports the existence of an alternative receptor that is both genetically and pharmacologically different from a classical estrogen receptor [97] and insensitive to the estrogen receptor blocker ICI 182, 780 [99]. A slow but persistent activation of MAP kinase p44/42 was observed after treatment with estradiol and TGF- $\beta 3$ to induce bFGF production from FS cells [100]. The estrogen receptor blocker ICI 182,780 did not block bFGF levels in FS cells induced by estradiol or by TGF- $\beta 3$ and estradiol, suggesting the possibility of a classical estrogen receptor-independent mechanism to increase bFGF production. Recent studies also provide evidence that TGF- $\beta$ and estradiol interact to increase bFGF production and release from FS cells via the estradiol receptorindependent PKC-Ras-MEK-MAP kinase p44/42 signaling pathway [100].

Involvement of PKC-Independent MAP Kinase p44/42 Signaling in Mediation of bFGF Action on Proliferation of Lactotropes. bFGF has been shown to cause proliferation of pituitary lactotropic cells $[31,101]$. bFGF is a member of a large group of FGF peptides that control multiple cellular processes, including cell migration, survival, proliferation and differentiation [102]. FGF peptides mediate their biological responses by binding to and activating a family of receptor tyrosine kinases (RTKs) designated as fibroblast growth factor receptors (FGFRs) [103]. The peptide bFGF possesses a dual receptor system consisting of tyrosine kinase FGFRs and heparin sulphate proteoglycans. It has been found that, in most cases, both of these components must be present in order for bFGF to trigger proliferation [104]. Binding of bFGF to the receptor is known to cause receptor dimerization and activation of the cytoplasmic domain. These RTKs subsequently activate multiple signaling pathways, including protein kinase $\mathrm{C}$ (PKC), Src kinases, Ras, and MAP kinase p44/42 [105, 106]. bFGF induces proliferation of lactotropic cells by activating MAP kinase p44/42 phosphorylation. Compelling evidence has recently been provided to show that bFGF increases lactotropic cell proliferation via PKC-independent Src-Ras-MEK-MAP kinase $\mathrm{p} 44 / 42$ signaling [107]. 


\section{Dopamine D2 Receptors and TGF- $\beta$ Type II Receptor Interaction}

Dopamine plays a key role in maintaining the normal function of lactotropes in the pituitary gland. Abnormalities in dopamine receptors and dopamine transporter function lead to hyperplasia of lactotropes [28, 108-110]. It is well known that estradiol inhibits dopamine release from the hypothalamus and downregulates dopamine $\mathrm{D} 2$ receptor activity in lactotropes $[15,84,111]$. The steroid decreases the potency of dopamine to inhibit PRL release by uncoupling the $\mathrm{D} 2$ receptors with $\mathrm{G} \alpha \mathrm{i} / \alpha \mathrm{o}$. The uncoupling of the $\mathrm{D} 2$ receptor might be the

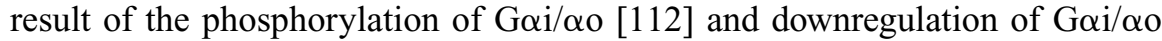
protein synthesis [113]. Estrogen also regulates the expression of a splicing factor thus favoring the production of the D2L [114]. The D2 receptor is a 7-transmembrane segment protein with a long third intracellular loop and a short intracellular C-terminus. The sixth exon of the D2 receptor gene is often excluded in the mature transcript, resulting in a short (29 amino acids shorter) isoform (D2S). Estradiol strongly favors the expression of the long isoform (D2L) mRNA over the short isoform D2S [114], thus causing uncoupling to the G protein $[115,116]$. It is interesting to note that ethanol, which increases lactotropic cell proliferation, also favors production of the D2L over the D2S isoform [84].

Treatment with dopamine agonists in some patients reverses the hyperprolactinemia [8]. This reversal supports the notion developed from experimental models that prolactinoma formation results from a disruption in dopamine function $[15,117]$. Our laboratory has recently identified a novel signaling cascade for lactotrope growth control involving the D2S, TGF- $\beta 1$ and its type II receptor [118]. It has recently been shown that transgenic mice, overexpressing D2S but not D2L, show pituitary hypoplasia; the D2S overexpressing mice also showed increased phosphorylated MAPK [28]. The MAPK system has also been shown to be involved in TGF- $\beta 1$-activated signaling in various cell types $[100,119]$. Hence, the possibility that the MAPK pathway is involved in dopamine-TGF- $\beta 1$ interaction mechanisms needs to be investigated.

Estrogen is known to reduce both the levels of dopamine and of dopamine D2 receptor activity in lactotropes $[15,84,120]$. By inhibiting dopamine, estrogen could inhibit TGF- $\beta 1$ and its receptor expression. Indeed, this association has been observed following long-term estrogen treatment [68]. In addition, we have observed that $\mathrm{GH} 3$ cells that have reduced functional dopamine D2 receptors have a low TGF- $\beta 1$ response and low TGF- $\beta 1$ production and reduced T $\beta$ RII levels [68]. We have also shown that PR1 cells, which did not respond to TGF- $\beta 1$ and did not express detectable TGF- $\beta 1$ or T $\beta$ RII, showed a lack of dopamine response and dopamine receptor binding. Hence, we have proposed that during sustained exposure, estrogen cancels the inhibitory effect of dopamine and thereby downregulates the inhibitory effect of TGF- $\beta 1$ on cell proliferation. This 


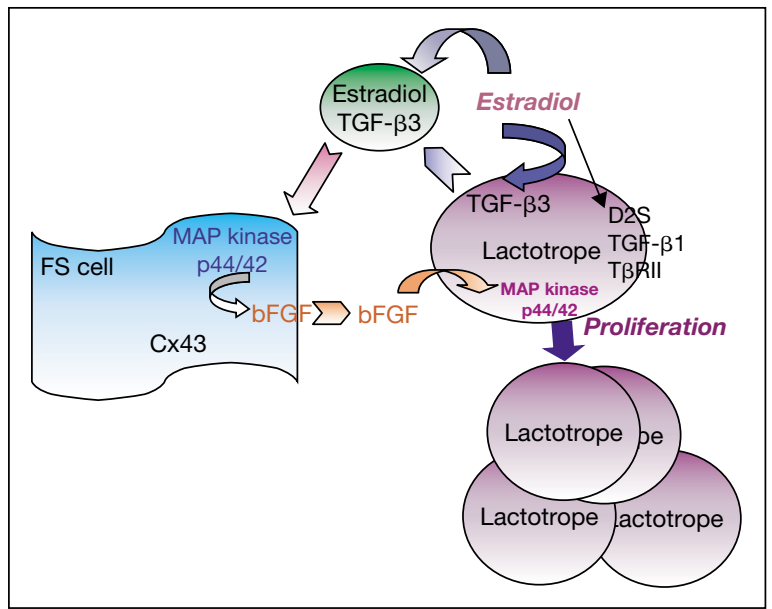

Fig. 1. Diagram summarizing the proposed roles of the FS cell in mediation of estradiol's actions on lactotropic cell proliferation. $\Rightarrow=$ Stimulation; $\rightarrow=$ inhibition.

may cause an alteration in the balance between positive and negative regulators of cell growth, resulting in abnormal lactotropic cell proliferation.

\section{Conclusion}

Lactotrope sensitivity to the mitogenic action of estradiol has important implications in normal physiology. During pregnancy, estrogen levels are elevated, which causes an increased number of lactotropes and increased plasma PRL, which is necessary for the initiation of milk production. When the level of estrogen returns to basal levels, the mitogenesis of lactotropes ceases. If estradiol levels remain elevated for prolonged periods, tumor formation can result. Although prolactinomas are quite common in the human population and are readily induced in animal models, our knowledge of the formation of these tumors is limited. The data presented in this review indicate that estradiol exposure may lead to prolactinoma formation via orchestrated events involving dopamine D2 receptors, TGF- $\beta$ isoforms and their receptors, as well as factors secondary to TGF- $\beta$ action. These data demonstrate that estradiol suppresses the dopamine D2 receptor's splice variant D2S to reduce TGF- $\beta 1-T \beta R I I$ inhibitory signaling in lactotropic cell proliferation. An estradiol inhibitory action on TGF- $\beta 1$ and or T $\beta$ RII expression leads to loss of growth-inhibitory control of TGF- $\beta 1$ in the lactotropes. The steroid also increases TGF- $\beta 3$ production and secretion from lactotropes. The secreted TGF- $\beta 3$ is transported to the neighboring FS cells, 
where it acts to induce the release of bFGF. The FS cell-derived b-FGF stimulates lactotropic cell proliferation as lactotropes escape from TGF- $\beta 1$ growth inhibition and are activated by estradiol to express FGF receptors. We presented data to show that MAP kinase p44/42 phosphorylation via the activation of Src kinases is required for cell growth. We postulate that the loss of TGF- $\beta 1$ growth-inhibitory control may be a contributing factor for lactotropic cell transformation. Taken together, these studies further our understanding not only of TGF- $\beta$ action in the anterior pituitary but also of the etiology of estradiolinduced prolactinomas (fig. 1). The identification of TGF- $\beta 1$ mediation of dopamine action also provides a novel possibility to consider the TGF- $\beta 1$ T $\beta$ RII signaling as a molecular target for treating prolactinomas.

\section{References}

1 Asa SL, Ezzat S: The cytogenesis and pathogenesis of pituitary adenomas. Endocr Rev 1998;19: 798-827.

2 Levy A, Lightman S: Molecular defects in the pathogenesis of pituitary tumors. Front Neuroendocrinol 2003;24:94-127.

3 Ishibashi M, Yamaji T: Effects of hypophysiotropic factors on growth hormone and prolactin secretion from somatotroph adenomas in culture. J Clin Endocrinol Metab 1985;60:985-988.

4 Hardy J: Ten years after the recognition of pituitary microadenomas; in Faglia G, Giovanelli MA, MacLeod RM (eds): Pituitary Microadenomas. New York, Academic Press, 1980, pp 7-14.

5 Miyai K, Ichihoza K, Kondo K, Mori S: Asymptomatic hyperprolactinoma in the general population mass screening by paired assays of serum prolactin. Clin Endocrinol 1986;25:549-552.

6 Kelley WN (ed): Text Book of Internal Medicine. New York, Lippincott, 1996, pp 1-1983.

7 MacLeod RM, Scapagnini U, Thorner MO: Pituitary Microadenomas. New York, Academic Press, 1980, pp 683-855.

8 Tonner D, Schlechte J: Contemporary therapy of prolactin-secreting adenomas. Am J Med Sci 1993;306:395-397.

9 Powell M, Lightman SL: The Management of Pituitary Tumors: A Handbook. Edinburgh, ChurchillLivingstone, 1996.

10 Van Thiel DH: Feminization of chronic alcoholic men: a formulation. Yale J Biol Med 1979;52:219-225.

11 Sarkar DK, Gottschall PE, Meites J: Relation of the neuroendocrine system to development of prolactin secretion pituitary tumors; in Meites J (ed): Neuroendocrinology of Aging. New York, Plenum Press, 1983, pp 353-376.

12 Sadoul JL, Thyss A, Freychet P: Invasive mixed growth hormone/prolactin secreting pituitary tumor: complete shrinking by octreotide withdrawal. Acta Endocrinol 1992;126:179-183.

13 DeNicola AF, Von Lawzewifsch IS, Kaplan E, Libertum C: Biochemical and ultrastructural studies of estrogen-induced pituitary tumors in F344 rats. J Natl Cancer Inst 1978;61:753-763.

14 Wicklund JA, Wertz N, Gorski J: A comparison of estrogen effect on uterine and pituitary growth and prolactin synthesis in F-344 and Holtzman rats. Endocrinology 1981;109:1700-1707.

15 Sarkar DK, Gottschall PE, Meites J: Damage to hypothalamic dopaminergic neurons is associated with development of prolactin-secreting tumors. Science 1982;218:684-686.

16 Banerjee SK, De A, Sarkar DK: Colocalization of prolactin and proliferating cell nuclear antigen in the anterior pituitary during estrogen-induced pituitary tumors. Cancer Lett 1994;87:139-144.

17 Shull JD, Spady TJ, Snyder MC, Johansson SL, Pennington KL: Ovary-intact, but not ovariectomized female ACI rats treated with $17 \beta$-estradiol rapidly develop mammary carcinoma. Carcinogenesis 1997;18:1595-1601. 
18 Lloyd RV: Estrogen-induced hyperplasia and neoplasia in the rat anterior pituitary gland. Am J Pathol 1983;113:198-206.

19 Gooren LJ, Assies J, Asscheman H, de Slegte R, van Kessel H: Estrogen-induced prolactinoma in a man. J Clin Endocrinol Metab 1988;66:444-446.

20 Garcia MM, Kapcala LP: Growth of a microprolactinoma to a macroprolactinoma during estrogen therapy. J Endocrinol Invest 1995;18:450-455.

21 Carol W, Lauterbach H, Klinger G, Unger A, Michels W: Prolactin stimulation using the metoclopramide test in females taking oral contraceptives. Zentralbl Gynakol 1988;110:1515-1521.

22 Shy KK, McTiernan AM, Daling JR, Weiss NS: Oral contraceptives use and the occurrence of pituitary prolactinoma. J Am Med Assoc 1983;249:2204-2207.

23 Luciano AA, Sherman BM, Chapler FK, Hauser KS, Wallace RB: Hyperprolactinemia and contraception: a prospective study. Obstet Gynecol 1985;65:506-511.

24 Holmgren U, Bergstrand G, Hagenfeldt K, Werner S: Women with prolactinoma-effect of pregnancy and lactation on serum prolactin and on tumor growth. Acta Endocrinol (Copenh) 1986;111: $452-459$.

25 Gíomez F, Reyes F, Fairman C: Nonpuerperal galactorrhea and hyperprolactinemia: clinical findings, endocrine features and therapeutic responses in 56 cases. Am J Med 1977;62:648-660.

26 Sherman B, Schlechte M, Halmi JNS, Chapler FK, Harris CE, Duello TM, Van Gilder J, Granner DK: Pathogenesis of prolactin-secreting pituitary adenomas. Lancet 1978;ii:1019-1021.

27 Chang RJ, Keye WR, Young JR, Willson CB, Jaffe RB: Detection, evaluation and treatment of pituitary microadenomas in patients with galactorrhea and amenorrhea. Am J Obstet Gynecol 1977; 128:356-363.

28 Laccarino C, Samad TK, Mathis C, Kercret H, Picetti R, Borrelli E: Control of lactotrope proliferation by dopamine: essential role of signaling through D2 receptors ERKs. Proc Soc Nat Acad Sci USA 2002;99:14530-14535.

29 Oomizu S, Chaturvedi K, Sarkar DK: Folliculostellate cells determine the susceptibility of lactotropes to estradiol's mitogenic action. Endocrinology 2004;145:1473-1480.

30 Schechter JE, Pattison A, Pattison T: Development of the vasculature of the anterior pituitary: ontogeny of basic fibroblast growth factor. Dev Dyn 1993;197:81-93.

31 Hentges S, Boyadjieva N, Sarkar DK: Transforming growth factor-beta3 stimulates lactotrope cell growth by increasing basic fibroblast growth factor from folliculostellate cells. Endocrinology 2000;141:859-867.

32 Välimäki M, Pelkonen R, Harkonen M, Tuomala P, Koistinen P, Roine R, Ylikahri R: Pituitarygonadal hormones and adrenal androgens in non-cirrhotic female alcoholics after cessation of alcohol intake. Eur J Clin Invest 1990;20:177-181.

33 Seki M, Yoshida K, Okamura Y: A study on hyperprolactinemia in female patients with alcoholics. Jpn J Alcohol Drug Depend 1991:26:49-59.

34 Teoh SK, Lex BW, Mendelson JH, Mello NK, Cochin J: Hyperprolactinemia and macrocytosis in women with alcohol and polysubstance dependence. J Stud Alcohol 1992;53:176.

35 Mendelson JH, Mello NK: Chronic alcohol effects on anterior pituitary and ovarian hormones in healthy women. J Pharmacol Exp Ther 1988;245:407-412.

36 Gavaler JS: Aging and alcohol: the hormonal status of postmenopausal women; in Sarkar DK, Barnes C (eds): Reproductive Neuroendocrinology of Aging and Drug Abuse. Boca Raton, CRC Press, 1994, pp 365-378.

37 Ida Y, Isujimararu S, Nakamaura K, Shirrao I, Mukasa H, Egami H, Nakazawa Y: Effects of acute and repeated alcohol ingestion on hypothalamic-pituitary-gonadal and hypothalamic-pituitaryadrenal functioning in normal males. Drug Alcohol Depend 1992;31:57-64.

38 Marchesi C, De Risio C, Campanini G, Majgini C, Piazza P, Grassi M, Chiodera P, Criro V: TRH test in alcoholics: relationship of the endocrine results with neuroendocrinological and neuropsychological findings. Alcohol Alcohol 1992;27:531-537.

39 Soyka M, Gorig E, Naber D: Serum prolactin increase induced by ethanol-a dose dependent effect not related to stress. Psychoneuroendocrinology 1991;16:441-446.

40 Kornet M, Goosen C, Thyssen JH, Van Ree JM: Endocrine profile during acquisition of freechoice alcohol drinking in rhesus monkeys: treatment with desglycinamide-(Arg 8)-vasopressin. Alcohol Alcohol 1991;27:403-410. 
41 Mello NK, Mendelson JH, Bree MP, Skupny A: Alcohol effects on naloxone-stimulated luteinizing hormone, follicle-stimulating hormone and prolactin plasma levels in female Rhesus monkeys. J Pharmacol Exp Ther 1988;245:895-904.

42 Sanchis R, Esquifino A, Guerri C: Chronic ethanol intake modifies estrous cyclicity and alters prolactin and LH levels. Pharmacol Biochem Behav 1985;23:221-224.

43 De A, Boyadjieva N, Pastorcic M, Sarkar DK: Potentiation of estrogen's mitogenic effect on the pituitary gland by alcohol consumption. International J Oncol 1995;7:643-648.

44 Stone R: Environmental estrogens stir debate. Science 1994;265:308-310.

45 Dees C, Asakari M, Foster JS, Ahamed S, Wimalasena J: DDT mimics estradiol stimulation of breast cancer cells to enter cell cycle. Mol Carcinogenesis 1997;18:107-114.

46 Krishnan AV, Stathis P, Permuth SF, Tokes L, Feldman D: Bisphenol A: an estrogenic substance released from polycarbonate flask during autoclaving. Endocrinology 1993;132:2279-2286.

47 Steinmetz R, Brown NG, Allen DL, Bigsby RM, Ben-Jonathan N: The environmental estrogen bisphenol A stimulates prolactin release in vitro and in vivo. Endocrinology 1997;138: 1780-1786.

48 Hunter DJ, Hankinson SE, Laden F: Plasma organochlorine levels and the risk of breast cancer. N Engl J Med 1997;337:1253-1258.

49 Goustin AS, Leof EB, Shipley GD, Moses HL: Growth factors and cancer. Cancer Res 1986;46: 1015-1029.

50 Clark BF: The effect of oestrogen and progesterone on uterine cell division and epithelial morphology in spayed, adrenalectomized rats. J Endocrinol 1971;50:527-528.

51 Parrot JA, Vigne JLB, Chu Z, Skinner MK: Mesenchymal-epithelial interactions in the ovaries follicle involve keratinocyte and hepatocytes growth factor production by theca cells and their action on granular cells. Endocrinology 1994;135:569-575.

52 Simon I, Huttner A, Said J, Spirina OM, Melmed S: Heparin-binding secretory transforming gene (hst) facilitates rat lactotrope cell tumorigenesis and induces prolactin gene transcription. J Clin Invest 1996;97:187-195.

53 Atkin SL, Landolt AM, Foy P, Jeffreys RV, Hipkin L, White MC: Effects of insulin-like growth factor-I on growth hormone and prolactin secretion and cell proliferation of human somatotrophinomas and prolactinomas in vitro. Clin Endocrinol (Oxf) 1994;41:503-509.

54 Sullivan NJ, Tashjian AH Jr: Platelet-derived growth factor selectively decreases prolactin production in pituitary cells in culture. Endocrinology 1983;113:639-645.

55 Borrelli E, Sawchenko PE, Evans RM: Pituitary hyperplasia induced by ectopic expression of nerve growth factor. Proc Natl Acad Sci USA 1992;89:2764-2768.

56 Tichomirowa M, Theodoropoulou M, Lohrer P, Schaaf L, Losa M, Uhl E, Lange M, Arzt E, Stalla GK, Renner U: Bacterial endotoxin (lipopolysaccharide) stimulates interleukin-6 production and inhibits growth of pituitary tumour cells expressing the toll-like receptor 4 . J Neuroendocrinol 2005; $17: 152-160$.

57 Fedele M, Pentimalli F, Baldassarre G, Battista S, Klein-Szanto AJ, Kenyon L, Visone R, De Martino I, Ciarmiello A, Arra C, Viglietto G, Croce CM, Fusco A: Transgenic mice overexpressing the wild-type form of the HMGA1 gene develop mixed growth hormone/prolactin cell pituitary adenomas and natural killer cell lymphomas. Oncogene 2005;24:3427-3435.

58 Onofri C, Carbia Nagashima A, Schaaf L, Feirer M, Lohrer P, Stummer W, Berner S, Chervin A, Goldberg V, Stalla GK, Renner U, Arzt E: Estradiol stimulates vascular endothelial growth factor and interleukin-6 in human lactotroph and lactosomatotroph pituitary adenomas. Exp Clin Endocrinol Diabetes 2004;112:18-23.

59 McAndrew J, Paterson AJ, Asa SL, McCarthy KJ, Kudlow JE: Targeting of transforming growth factor-alpha expression to pituitary lactotrophs in transgenic mice results in selective lactotroph proliferation and adenomas. Endocrinology 1995:136:4479-4488.

60 Cruz-Soto ME, Scheiber MD, Gregerson KA, Boivin GP, Horseman ND: Pituitary tumorigenesis in prolactin gene-disrupted mice. Endocrinology 2002;143:4429-4436.

61 Hentges ST, Low MJ: Ovarian dependence for pituitary tumorigenesis in D2 dopamine receptordeficient mice. Endocrinology 2002;143:4536-4543.

62 Massagué J: Receptors for the TGF- $\beta$ family. Cell 1992;69:1067-1070.

63 Moses HL, Young EY, Pietenpol JA: Regulation of epithelial proliferation by TGF-beta. Cell 1990;63:245-247. 
64 Sporn MB, Roberts AB: Autocrine growth factors and cancer. Nature 1985;313:745-747.

65 Sarkar DK, Kim KH, Minami S: Transforming growth factor- $\beta 1 \mathrm{mRNA}$ and protein expression in the pituitary gland and its action on PRL secretion and lactotropic growth. Mol Endocrinol 1992;6:1825-1833.

66 Minami S, Sarkar DK: Transforming growth factor- $\beta 1$ inhibits prolactin secretion and lactotropic cell proliferation in the pituitary of estrogen-treated Fischer 344 rats. Neurochem Int 1997;30: 499-506.

67 De A, Morgan TE, Speth RC, Boyadjieva N, Pastorcic M, Sarka DK: Pituitary lactotrope expresses TGF- $\beta$ type II receptor mRNA and protein and contains $\left[{ }^{125} \mathrm{I}\right] \mathrm{TGF}-\beta 1$-binding sites. J Endocrinol 1996;149:19-27.

68 Pastorcic M, De A, Boyadjieva N, Vale W, Sarkar DK: Reduction in the expression and action of transforming growth factor $\beta 1$ on lactotropes during estrogen-induced tumorigenesis. Cancer Res 1995;55:4892-4898.

69 Pastorcic M, Sarkar DK: Downregulation of TGF- $\beta 1$ gene expression in anterior pituitary cells treated with forskolin. Cytokine 1997;9:106-111.

70 Hentges S, Pastorcic M, De A, Boyadjieva N, Sarkar DK: Opposing actions of two transforming growth factor-beta isoforms on pituitary lactotropic cell proliferation. Endocrinology 2000;141:1528-1535.

71 Roberts AB, Kim SJ, Noma T, Glick AB, Lafyatis R, Lechleider R, Jakowlew SB, Geiser A, O'Reilly MA, Danielpour D: Multiple forms of TGF-beta: distinct promoters and differential expression. Ciba Found Symp 1991;157:7-15.

72 Day RN, Koike S, Sakai M, Muramatsu M, Maurer RA: Both Pit-1 and the estrogen receptor are required for estrogen responsiveness of the rat prolactin gene. Mol Endocrinol 1990;4:1964-1971.

73 Yang NN, Venugopalan M, Sushant H, Glasebrook A: Identification of an estrogen response element activated by metabolites of 17 $\beta$-estradiol and raloxifene. Science 1996;273:1222-1224.

74 Derynck R: TGF- $\beta$-receptor-mediated signaling. TIBS 1994;19:548-553.

75 Arrick BA, Korc M, Derynck R: Differential regulation of expression of three transforming growth factor beta species in human breast cancer cell lines by estradiol. Cancer Res 1990;50:299-303.

76 Sarkar DK, Hentges ST, De A, Reddy RHR: Hormonal control of pituitary prolactin-secreting tumors. Front Biosci 1998;3:D934-D943.

77 Shida N, Ikeda H, Takashi Y, Oshima M, Taketo MM, Miyoshi I: Estrogen-induced tumorigenesis in the pituitary gland of TGf- $\beta(+/-)$ knockout mice. Biochim Biophys Acta 1998;1407:79-83.

78 Nakajima T, Yamaguchi H, Takahashi K: S 100 protein in folliculostellate cells of the rat pituitary anterior lobe. Brain Res 1980;191:523-531.

79 Gracia-Navarro F, Porter D, Garcia-Navarro S, Licht P: Immunocytochemical and ultrastructural study of the frog (Rana pipiens) pars distalis with special reference to folliculostellate cell function during in vitro superfusion. Cell Tissue Res 1989;256:623-630.

80 Gloddek J, Pagotto U, Paez Pereda M, Arzt E, Stalla GK, Renner U: Pituitary adenylate cyclaseactivating polypeptide, interleukin- 6 and glucocorticoids regulate the release of vascular endothelial growth factor in pituitary folliculostellate cells. J Endocrinol 1999;160:483-490.

81 Vankelecom H, Andries M, Billiau A, Denef C: Evidence that folliculostellate cells mediate the inhibitory effects of interferon-gamma on hormone secretion in rat anterior pituitary cell cultures. Endocrinology 1992;130:3537-3546.

82 Horvath E, Kovacs K: Folliculostellate cells of the human pituitary: a type of adult stem cell? Ultrastruct Pathol 2002;26:219-228.

83 Allen DL, Mitchner NA, Uveges TE, Nephew KP, Khan S, Ben-Jonathan N: Cell-specific induction of c-fos expression in the pituitary gland by estrogen. Endocrinology 1997;138:2128-2135.

84 Oomizu S, Boyadjieva N, Sarkar DK: Ethanol and estradiol modulate alternative splicing of dopamine D2 receptor mRNA and abolish the inhibitory action of bromocriptine on prolactin release from the pituitary gland. Alcohol Clin Exp Res 2003;27:975-980.

85 Soji T, Mabuchi Y, Kurono C, Herbert DC: Folliculo-stellate cells and intercellular communication within the rat anterior pituitary gland. Microsc Res Tech 1997;39:138-149.

86 Morand I, Fonlupt P, Guerrier A, Trouillas J, Calle A, Remy C, Rousset B, Munari-Silem Y: Cellto-cell communication in the anterior pituitary: evidence for gap junction-mediated exchanges between endocrine cells and folliculostellate cells. Endocrinology 1996;137:3356-3367. 
87 Bennett MV, Barrio LC, Bargiello TA, Spray DC, Hertzberg E, Saez JC: Gap junctions: new tools, new answers, new questions. Neuron 1997;6:305-320.

88 Evans WH, Martin PE: Gap junctions: structure and function. Mol Membr Biol 2002;19:121-136.

89 Kabir N, Chaturvedi C, Liu LS, Sarkar DK: TGF- $\beta 3$ increases gap-junctional communication among folliculostellate cells to increase bFGF release. Endocrinology 2005;146:4054-4060.

90 Keshamouni VG, Mattingly RR, Reddy KB: Mechanism of 17-beta-estradiol-induced Erk1/2 activation in breast cancer cells: a role for HER2 and PKC-delta. J Biol Chem 2002;277:22558-22565.

91 van der Burg B, van Selm-Miltenburg AJ, de Laat SW, van Zoelen EJ: Direct effects of estrogen on c-fos and c-myc protooncogene expression and cellular proliferation in human breast cancer cells. Mol Cell Endocrinol 1989;64:223-228.

92 Weigel NL: Steroid hormone receptors and their regulation by phosphorylation. Biochem J 1996;319:657-667.

93 Reddy KB, Yee D, Hilsenbeck SG, Coffey RJ, Osborne CK: Inhibition of estrogen-induced breast cancer cell proliferation by reduction in autocrine transforming growth factor alpha expression. Cell Growth Differ 1994;5:1275-1282.

94 Arteaga CL, Coronado E, Osborne CK: Blockade of the epidermal growth factor receptor inhibits transforming growth factor alpha-induced but not estrogen-induced growth of hormone-dependent human breast cancer. Mol Endocrinol 1988;2:1064-1106.

95 Dickson RB, Lippman ME: Estrogenic regulation of growth and polypeptide growth factor secretion in human breast carcinoma. Endocr Rev 1987;8:29-34.

96 Korovkina VP, Brainard AM, Ismail P, Schmidt TJ, England SK: Estradiol binding to maxi-K channels induces their down-regulation via proteasomal degradaion. J Biol Chem 2004;272:1217-1223.

97 Nadal A, Ropero AB, Fuentes E, Soria B: The plasma membrane estrogen receptor: nuclear or unclear. Trends Pharmacol Sci 2001;22:597-599.

98 Watson CS, Norfleet AM, Pappas TC, Gametchu B: Rapid actions of estrogens in GH3/B6 pituitary tumor cells via a plasma membrane version of estrogen receptor-alpha. Steroids 1999;64: 5-13.

$99 \mathrm{Gu}$ Q, Korach KS, Moss RL: Rapid action of 17beta-estradiol on kainate-induced currents in hippocampal neurons lacking intracellular estrogen receptors. Endocrinology 1999;140:660-666.

100 Chaturvedi K, Sarkar DK: Involvement of PKC dependent p44/42 MAP kinase signaling pathway for cross-talk between estradiol and TGF- $\beta 3$ in increasing bFGF in folliculostellate cells. Endocrinology 2004;145:706-715.

101 Prysor-Jones RA, Silverlight JJ, Jenkins JS: Oestradiol, vasoactive intestinal peptide and fibroblast growth factor in the growth of human pituitary tumour cells in vitro. J Endocrinol 1989;120:171-177.

102 Naski MC, Ornitz DM: FGF signaling in skeletal development. Front Biosci 1998;3:D781-D794.

103 Jaye M, Schlessinger J, Dionne CA: Fibroblast growth factor receptor tyrosine kinases: molecular analysis and signal transduction. Biochem Biophys Acta 1992;1135:185-199.

104 Delehedde M, Lyon M, Sergeant N, Rahmoune H, Fernig DG: Proteoglycans: pericellular and cell surface multireceptors that integrate external stimuli in the mammary gland. J Mammary Gland Biol Neoplasia 2001;6:253-273.

105 Mohammadi M, Dionne CA, Li W, Li N, Spivak T, Honegger AM, Jaye M, Schlessinger J: Point mutation in FGF receptor eliminates phosphatidylinositol hydrolysis without affecting mitogenesis. Nature 1992;358:681-684.

106 Klint P, Kanda S, Kloog Y, Claesson-Welsh L: Contribution of Src and Ras pathways in FGF-2 induced endothelial cell differentiation. Oncogene 1999;18:3354-3364.

107 Chaturvedi K, Sarkar DK: Mediation of basic fibroblast growth factor-induced lactotropic cell proliferation by Src-Ras-mitogen-activated protein kinase p44/42 signaling. Endocrinology 2005;146:1948-1955.

108 Kelly MA, Rubinstein M, Asa SL, Zhang G, Saez C, Bunzow JR, Allen RG, Hnasko R, Ben-Jonathan N, Grandy DK, Low MJ: Pituitary lactotroph hyperplasia and chronic hyperprolactinemia in dopamine D2 receptor-deficient mice. Neuron 1997;19:103-113.

109 Saiardi A, Bozzi Y, Baik JH, Borrelli E: Antiproliferative role of dopamine: loss of D2 receptors causes hormonal dysfunction and pituitary hyperplasia. Neuron 1997;19:115-126.

110 Bosse R, Fumagalli F, Jaber M, Giros B, Gainetdinov RR, Wetsel WC, Missale C, Caron MG: Anterior pituitary hypoplasia and dwarfism in mice lacking the dopamine transporter. Neuron 1997;19:127-138. 
111 Ben-Jonathan N, Hnasko R: Dopamine as a prolactin (PRL) inhibitor. Endocr Rev 2001;22: 724-763.

112 Maus M, Homburger V, Bockaert J, Glowinski J, Premont J: Pretreatment of mouse striatal neurons in primary culture with $17 \beta$-estradiol enhances the pertussis toxin-catalyzed ADP-ribosylation of $\mathrm{G} \alpha_{\text {oi }}$ protein subunits. J Neurochem 1990;55:1244-1251.

113 Livingstone JD, Lerant A, Freeman ME: Ovarian steroids modulate responsiveness to dopamine and expression of G-proteins in lactotropes. Neuroendocrinology 1998;68:172-179.

114 Guivarc'h D, Vincent J-D, Vernier P: Alternative splicing of the D2 dopamine receptor messenger ribonucleic acid is mediated by activated sex steroid receptors in the MMQ prolactin cell line. Endocrinology 1998;139:4213-4221.

115 Kobilka BK, Kobilka TS, Danil K, Regan JW, Caron MG, Lefkowitz RJ: Chimeric $\alpha 2$-, $\beta 2$-adrenergic receptors: delineating of domaine involved in effector coupling and ligand binding specificity. Science 1988;240:1310-1316.

116 Guiramand J, Montmayeur J-P, Crealine J, Bhatia M, Borrelli E: Alternative splicing of the dopamine D2 receptor directs specificity of coupling to G-proteins. J Biol Chem 1995;270:7354-7358.

117 Asa SL, Kelly MA, Grandy DK, Low ML: Pituitary lactotroph adenomas develop after prolonged lactotroph hyperplasia in dopamine D2 receptor-deficient mice. Endocrinology 1999;140:5348-5355.

118 Sarkar DK, Chaturvedi K, Oomizu S, Boyadjieva N, Chen CP: Dopamine and TGF- $\beta 1$ interact to inhibit the growth of pituitary lactotropes. Endocrinology 2005;146:4179-4188.

119 Nagineni CN, Samuel W, Nagineni S, Pardhasaradhi K, Wiggert B, Detrick B, Hooks JJ: Transforming growth factor-beta induces expression of vascular endothelial growth factor in human retinal pigment epithelial cells: involvement of mitogen-activated protein kinases. J Cell Physiol 2003;197:453-462.

120 Raymond V, Beaulieu M, Labrie F: Potent antidopaminergic activity of estradiol at the pituitary level on prolactin release. Science 1978;200:1173-1175.

Dipak K. Sarkar

Endocrine Program, Biomedical Division of the

Center of Alcohol Studies and Department of Animal Sciences

Rutgers, The State University of New Jersey

84 Lipman Drive

New Brunswick, NJ 08901-8525 (USA)

Tel. +1 732932 1529, Fax +1 732932 4134, E-Mail sarkar@AESOP.rutgers.edu 